\title{
The Role of Principal Leadership to Improve Teacher Performance in Islamic Elementary School
}

\author{
Citra Aulia Uzliva, Yatim Riyanto, M.V. Roesminingsih \\ Department of Education Management \\ Universitas Negeri Surabaya \\ Surabaya, Indonesia \\ citrauzliva16070845026@mhs.unesa.ac.id
}

\begin{abstract}
The purposes of this study were for 1) the role of principal in an effort to improve school achievement; 2) teacher performance; 3) principal effort to improve school performance. This study used a qualitative approach with a case study design. The results show that 1 ) the leadership role of the principal has met the EMASLIM standard which has been proven from interviews, observations and documentation, 2) the performance of teachers already meet the existing law and teachers prefer the process to get quality results, and 3) the principal has sought all activities that support the effort to improve the performance of teachers, either by attending seminars, workshops, teacher training and evaluation.
\end{abstract}

\section{Keywords - principal leadership role; teacher performance}

\section{INTRODUCTION}

School is a leading institution to develop the potential of human resources. Various approaches, techniques, and methods continue to be developed to create a conducive school environment in order to develop human potential in accordance with the character and personality.

The birth of UU no. 14 of 2005 on Teachers and Lecturers [1] and Government Regulation no. 32 of 2013 on the latest National Education Standards [2], is basically a government policy which contains efforts to organize and improve the quality of principals in Indonesia.

The development of science and technology has brought changes in almost every aspect of human life. In one side, the changes are beneficial to human life, but on the other sides, these changes have also brought people into the era of fierce global competition. In order to be able to play a role in global competition, the Indonesian people need to continually develop and improve the quality of human resources, especially the next generation intellectuals.

In an educational organization, the highest leadership is the principal, who has the critical responsibility and role to improve the quality of the school and manage the school organization to achieve its goals. As such responsibility in educational institutions is to manage or organize educators and education personnel. According to Sumidjo [3], a principal is a functional teacher who is assigned to lead a school where the learning process is organized or the place where interaction occurs between the teacher giving the lesson and the student receiving the lesson.
At the operational level, the principal is the person who is at the forefront of coordinating efforts to improve the quality of learning and improvement for the performance of human resources in the school, especially to improve the quality of schools.

In addition to the principal, the role of teachers as a reliable and qualified educator is one of the strategic factors to realize the goals of national education. In the National Education System UU no. 20 Year 2003 Article 42 [4], paragraph 1 mentioned that educators must have minimum qualifications and certification in accordance with the level of teaching authority, healthy physical and spiritual, and have the ability to realize the goals of national education. To become a teacher, as an early stage must meet the minimum qualification requirement that has a teacher education background/public. Once the teacher meets the qualification requirements, then the teacher will and is in the stage of competence. However, the phenomenon shows that the competence of educators in schools in order to produce the expected students is still not optimal. Therefore, the educators are required to be more professional in carrying out the noble task without prioritizing private or group interests except with full dedication or high dedication by becoming a better teacher, progressive, productive, professional and competent [5].

In fact, the seeded schools have been popping up in big cities. For example, the pre-eminent schools of SD Al Hikmah Surabaya, SD Muhammadiyah 4 Pucang Surabaya and some others which are able to contribute significantly in shaping intelligent and skilful human beings, both from the improvement of intellectual, emotional, and spiritual intelligence. Success achieved to attract the attention of the community to send their children to school, although the risk of having to pay more expensive tuition fee than other schools. In fact, not only parents are obsessed, but also policy makers in the field of education. Although it is not supported by adequate costs, they try to encourage the emergence of leading schools, or at least superior classes ranging from kindergarten, elementary, junior high school.

Islamic Elementary School Mojokerto City implements the education system with the National Curriculum combined with the Al-Azhar's Typical Curriculum and enriched with Islamic Religion knowledge through 
additional materials. The Islamic values (Qur'an, Juz 'Amma, daily do'a-do'a, hadith and Asmaul Husna) are held daily by all students, until memorized without memorizing (habituation). Computer, English and Arabic lessons have been introduced since the first grade. The learning system is emphasized on active learning and learning by doing. Seating arrangement are always changed every month in accordance with the pattern of learning. It is a full day school (5 days school). Each student has a Liaison Book, a daily Fiqh Book, and a Book of Prayer. It has daily clean \& healthy living habits.

Additionally, there are 2 report cards in student ratings. To find out child development, there are Attitudes \& Behavior report cards. Academic Officers are distributed at the end of each semester. Semester midterm reports are distributed each mid-semester to see the child's academic ability as well as the development of the Al-Qur'an reading and the Report of Child Health to monitor the child's health record regularly. Islamic Elementary School is an Aaccredited school (highest score) from the National Accreditation Board of the Ministry of Education.

The programs held at Islamic Elementary School aim to develop the talents and potential of children, as well as provide future provisions by actively engaging children in every activity. Such success requires effective implementation of the principal's leadership. In addition to the effectiveness of the principal's leadership, it is required to contribute the efforts to develop and improve the performance of teachers through education and training both formally and informally. It also shows the role of stakeholders and school residents which is very influential to determine the progress of school. The principal's activities in carrying out the policies are demanded by donors and the implementation of their duties, the management developed, the roles, and the personal skills they possess to advance the school are interesting to examine.

This reason is supported by the results of research conducted by experts indicating that one of the principal's roles especially about the style of each leader provides an indication of the diverse outcomes. There are five elements of a school's effectiveness: leadership, strong school administration, high expectations for ability of students, the establishment of a conducive school atmosphere, emphasis on basic skills, and the frequency of monitoring people who make a plan [6]. Marzano, Waters, and McNulty [7] explain that the existence of a good principal has very large contribution to superior schools. There has never been a superior school which has a high school principal.

Based on the preliminary study, the role carried out on the principal of Islamic Elementary School Mojokerto are among others:

First, the role of headmaster in Islamic Elementary School Mojokerto, as the manager who creates school performance challenge (the gap between the real performance and the expected performance) from which the objectives will be formulated by the school, followed by selecting the functions needed to reach the target, and then performing SWOT analysis to find the inhibited factors to which then working to solve the problem.

Second, in addition to the task of becoming the principal administrator of Islamic Elementary School Mojokerto who manages everything related to school, the principal also seeks a compact and intelligent teamwork, fosters solidarity so as to create a climate that can ensure the certainty of school output / output.

Third, the principal of Islamic Elementary School Mojokerto is able to create a situation which can foster creativity and provide opportunities for teachers to do creativity to produce something new. In other words, the principal encourages teachers to take and manage risks and protect the wrong circumstances. From this, it can be seen the role of the principal of Islamic Elementary School Mojokerto as a motivator who can provide motivation to staff and teachers to always improve the quality of school well.

The uniqueness can be explained as follows. First, the uniqueness of the principal's leadership can improve teacher performance. In addition, the approach is performed with kinship relationship. This is done by approaching all teachers and families so that a good relationship between the principal with the teacher and with the community.

Second, the importance of school achievement is along with the rapid development of the era, thus demanding changes from various sectors to compete along with the existing global flow. School performance is determined from the performance of teachers, a performance by teachers in carrying out duties as educators. The quality of teacher performance will determine the quality of education because teacher is someone who most often interacts with students in the learning process.

Based on the above background, the researcher is interested in conducting research entitled "The Role of Principal Leadership in Improving Teacher Performance in Islamic Elementary School"

\section{RESEARCH METHODS}

Research on the role of school principals in improving teacher performance in Islamic Elementary School Mojokerto used a descriptive qualitative approach with case study research design. In qualitative research, the researcher went directly to the field to collect the data. Data collection techniques used in research at Islamic Elementary School Mojokerto were interview techniques, observation and documentation studies. While the data analysis techniques used were data reduction, data presentation, and data verification [8]. Steps which must be passed in conducting the research were the pre-research stage, during the field and after the field.

\section{RESULTS AND DISCUSSION}

Here is the discussion of each focus on the Principal Leadership Role in Improving Teacher Performance in Islamic Elementary School: 


\section{A. The Role of Principal in Improving School Achievement in Islamic Elementary School}

Leadership is an important force in the framework of management, and therefore effective leadership skill is the key to become an effective manager. The essence of leadership is followership, the willingness of others or subordinates to follow the leader's wishes, causing a person to become a leader. In other words, the leader will not be formed if there are no subordinates.

In another opinion Lussier and Achua [9] explain that Leadership is the influencing process of leaders and followers to achieve organizational objective through change. The point is more or less: Leadership is the process of influencing leaders and followers to achieve organizational goals through change. Then Fiedler [10] defines leadership as the individual within the group that provides guidance and organizational tasks relevant to group activities. While Stogdill [11] provides the definition of leadership as the process of influencing group activities organized toward the goal determination and achievement. Meanwhile, Terry [12] argues that leadership is an activity affecting people so they like to try to achieve group goals. Suhendra [13] defines that leadership is the ability to influence the behaviour of others to conduct activities directed by a leader. On the other hand, Kartono [12] argues that leadership is the ability to influence the constructive to others to make a cooperative effort to achieve the goals that have been declared. Further said the leader must be adept at carrying out his leadership.

Based on the above definitions, leadership has several implications, among others: First: leadership means involving people or other parties, i.e. employees or subordinates (followers). Employees or subordinates must have the will to receive direction from the leader. However, without employees or subordinates, leadership will not exist. Second: an effective leader is an empowerment with his power (his or her power) able to arouse his followers to achieve satisfactory performance. Third: leadership must have honesty towards self and others (communication) in building the organization.

In this case the role of school principal in an effort to improve the performance of teachers in Islamc Elementary School of Mojokerto was good and in accordance with the theory. From the research results, the role of principal in elementary school always prioritizes customer satisfaction. Customers here are students and parents who have already secured their children at Islamic Elementary School, with attentive comfort, so they do not feel disadvantaged by the cost of a slightly more expensive school than public school.

\section{B. Performance of Teachers at Islamic Elementary School Mojokerto}

Performance of teachers can be interpreted as the success of teachers in carrying out educational tasks in accordance with responsibilities and authority based on performance which established during a certain period within the framework of achieving educational goals.

With regard to teacher performance standards, Sahertian [14] states that teacher performance standards relate to teacher quality in performing their tasks such as: 1) working individually, 2) preparing and learning planning, 3) learning media, 4) engaging students in various learning experiences, and 5) active leadership of teachers.

Teacher performance has certain specifications. Teacher performance can be viewed and measured based on competency specification / criteria that every teacher must possess. In relation to the performance of teachers, the form of behaviour in question is the activities of teachers in the learning process.

In the process of teaching and learning, teachers in Islamic Elementary School Mojokerto have done a good job, from preparing teaching materials to creating pleasant learning climate.

The presence of teachers in the teaching and learning process plays an important role. The role of teachers in the teaching process cannot yet be replaced by machines, radios, or other technologies because there are still many human elements needed in the process such as, attitude, value system, feeling, motivation, and others. This is where the role of professional teachers is needed.

\section{Principal Efforts in Improving Teacher Performance in Islamic Elementary School Mojokerto}

The principal's efforts in improving teacher performance are to stimulate his subordinates by engaging in activities related to school innovation and encouraging his subordinates to actively participate in seminars, workshops and institutional coaching activities. This reflects that the Islamic elementary school is an innovative school principal. As disclosed by De Jong and Hartog [15], there are 13 types of behaviour which spur the emergence of innovation. Thirteen behaviours are related to the appearance and application of innovation ideas. These behaviours are as follows:

Model examples of innovative behaviour; b) Provide intellectual stimulation; c) Invite employees to share knowledge; d) Provide vision direction; e) Consulting; f) Delegating; g) Support innovation; h) Provide positive feedback on initial ideas and stages of implementation of innovation, and ask consumer opinion to know their reaction to innovation activities; i) Recognition; j) Provide a reward; k) Provide facility support; 1) Monitoring innovative activities, m) Assigning assignments. Ancok (2012: 134-135).

Based on the theory, all the points are in the leadership of Islamic Elementary School Plus Al Azhar. So, from the above description it can be concluded that the principal of Islamic Elementary School Plus Al Azhar always gives directives and guidance, which aims to improve the quality of teacher performance in accordance with the purpose of school vision.

\section{CONCLUSION AND SUGGESTION}

\section{A. Conclusion}

1) Efforts made by the principal in improving teacher performance i.e:

a. Being able to model innovative behaviour to subordinates by frequently modifying student activities to make them more interesting from the previous year 
b. Is able to provide intellectual stimulation by channeling knowledge that he has.

c. Invitea subordinates to follow and be active in activities related to school innovation, whether it be seminars, workshops, and coaching.

d. Embeds a vision to subordinates at every weekly meeting. With the aim that subordinates work right on target according to the school vision and mission.

e. Supports innovation, by rewarding subordinate and innovative subordinates for school progress.

2) In maintaining the harmony of the principal of Islamic Elementary School Plus Al Azhar create a group in social media called whatsapp. This aims to keep the communication running despite outside working hours. With this application information about the school that should be delivered impromptu can be quickly conveyed.

\section{B. Suggestion}

It is suggested to the principal to always pay attention to teacher performance by creating activities which enable teachers to develop and support teacher performance improvement.

\section{REFERENCES}

[1] U.-U. R. Indonesia, "No. 14 Tahun 2005," Guru dan Dosen Daft. Pustaka, 2005.

[2] P. P. Nomor, "tahun 2013 tentang Standar Nasional pendidikan," Diunduh dari http//sindikker. dikti. go. id/dok/PP/PP3, 32AD.

[3] W. Sumidjo, "Kepemimpinan kepala sekolah, tinjauan teoritik dan permasalahannya," PT Graf. Persada. Jakarta, 2002.

[4] R. I. Undang-Undang, "no. 20 tahun 2003 tentang Sistem Pendidikan Nasional," Bandung: Citra Umbara, 2003.

[5] M. Roqib, "Nurfuadi. Kepribadian Guru Upaya Mengembangkan Kepribadian Guru yang Sehat di Masa Depan.” Purwokerto: STAIN Purwokerto Press, 2011.

[6] Surjadi, Pengembangan kinerja pelayanan publik. Refika Aditama, 2009.

[7] R. J. Marzano, T. Waters, and B. A. McNulty, School leadership that works: From research to results. ASCD, 2005.

[8] J. W. Creswell, Educational research: Planning, conducting, and evaluating quantitative and qualitative research. 2012.

[9] R. N. Lussier and C. F. Achua, Leadership: Theory, application, \& skill development. Nelson Education, 2015.

[10] F. E. Fiedler, "The Contingency model: H Theory of Leadership Effectiveness," Small Groups Key Readings, p. 369, 2006.

[11] R. M. Stogdill, Leadership, membership and organization. Oxford University Press Oxford, UK, 1997.

[12] K. Kartono, "Pemimpin dan Kepemimpinan: Apakah Kepemimpinan Abnormal itu Badan Penerbit Rajawali Press, 2013.” Jakarta, 2013.

[13] K. Suhendra and A. D. Kadmasasmita, Peranan Birokrasi dalam Pemberdayaan Masyarakat. Alfabeta, 2006.

[14] P. A. Sahertian, Konsep dasar \& teknik supervisi pendidikan: dalam rangka pengembangan sumber daya manusia. Penerbit Rineka Cipta, 2000.

[15] J. P. J. De Jong and D. N. Den Hartog, "How leaders influence employees' innovative behaviour," Eur. J. Innov. Manag., vol. 10, no. 1, pp. 41-64, 2007. 